\title{
DEVELOPMENT OF THE GRAIN CROPS SUPPLY CHAIN MODEL
}

\author{
Vinnytsia National Technical University
}

The possibility of optimization of the grain crops supply chain taking into account the interests of the farm is investigated in the work. The main trends in the agricultural sector of Ukraine, which directly or indirectly affect the activities of the farm, are analyzed in the work.

It is established that the choice of the most optimal means of transport for grain crops transportation allows the farm to reduce the cost of the logistics supply chain, which in turn will lead to increased profitability and expansion of the agricultural sector. The solution to this problem is possible through the modeling of the grain crops logistics supply chain. To form a model of the grain crops supply chain the process of grain delivery as a system that contains many acceptable alternatives for making the most rational decision. The proposed model is presented in form of a "black box" model. The objective function of this model for farms is to make a rational decision on the process of grain delivery in order to maximize profits by optimizing the costs of such supply chain and ensuring the development of farming as an activity.

The original variables of this model are: grain crops yields and grain crops humidity; farm's sown area; harvesting equipment efficiency; own granaries capacity; cost for grain storage in own granary or for elevator service; grain share depending on the storage place; sales price of grain crops: to the internal buyer, at the grain reception center, at the port terminal, and also weather and climate conditions during harvest (favorable / unfavorable conditions).

The initial indicators that will characterize the success of the grain delivery process will be the following one: harvest duration, harvest amount, trucking cost, average daily harvest duration, additional costs obtained by managing grain humidity, magnitude of crop losses due to the harvest duration, magnitude of losses due to the grain quality reduction (with mixing, without mixing).

The proposed model will consider all these factors and their impact on harvesting, storage and transportation of grain crops, and will help to take into account the costs for farms depending on the situation.

Key words: grain logistics, farming, supply chain, «black box» model.

\section{Problem statement}

The active development of the agricultural sector in Ukraine, in particular the cultivation of grain crops, contributes to the activation of its subjects. Today we see not only the development of agricultural holdings, but also the farms growth. Thus, as of July 1, 2021 the number of farms is 48.4 thousand, which is lower than in 2013 - 49.1 thousand (a record number of farmers in Ukraine). However, from 2015 to 2021 only a positive dynamics of farms growth is observed, in general by $11 \%$ [1].

Along with the development of farming in Ukraine, farmers face the problem of choosing a place to store products, vehicle types, grain species and new technologies for harvesting. All these factors, individually and in combination, affect the profitability of a farm. That is why a rational assessment of the costs that take part in the supply chain of grain products is of practical importance and is of interest to the farm.

\section{Main part}

The number of small farms is $69 \%$ havingsize of the harvested area up to 200 ha (Fig. 1) of the total number of agricultural enterprises in Ukraine to date. Therefore, decision-making by a farm is important not only to increase its own profitability, but also for the agricultural sector of Ukraine. Having considered the main trends in the agricultural sector of Ukraine, which directly or indirectly affect the activities of the farm, it is necessary to highlight the following:

1. The influence of agricultural holding companies

The Ukrainian agricultural industry is characterized by the presence of agricultural holdings. Although agricultural holdings cultivate only $10 \%$ of arable land, their political influence extends throughout the country. The access to new export markets, the construction of elevators, the gradual purchase of leased land, the desire to minimize the involvement of employees and the purchase of modern equipment, all these phenomena are inherent in Ukrainian agricultural holdings [2].

2. Use of high-yielding grains.

The increase in grain yield index from $27.4 \mathrm{c} /$ ha to $42.9 \mathrm{c} /$ ha [3], which can be explained by the use of high-yielding grain species, as well as the combination of the best species and dominant agricultural systems in agriculture. Larger harvests require greater demands on services and infrastructure in the logistics supply 
chains of grain: the grain storage on a farm,the gain transportation, the grain storage in the country, the grain storage and transshipment in ports.

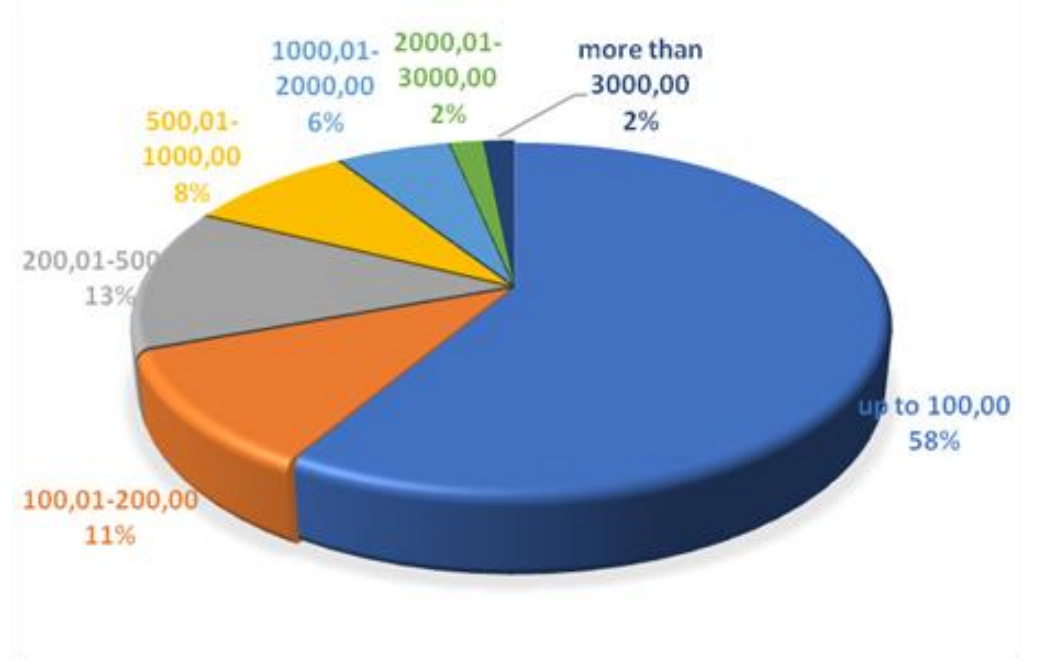

Fig. 1. Grouping of enterprises by size of the harvested area (ha) of the main crops in 2020

\section{Use of modern harvesting equipment}

The combination of increased yields and grain cultivation encourages farmers to use more efficient harvesting equipment. Improving the efficiency of the harvesting and transport complex allows to reduce the duration of the harvest, which in turn can lead to additional costs for the grain storage.

4. The method of grain storage.

In Ukraine today there are more than 1,200 elevators and granaries. Most of them have a well-developed infrastructure, their own laboratories for analysis, and railway tracks. There is also a tendency to active building of linear elevators, modernization existing granaries in order to increase their energy efficiency. At the same time, the demand for granaries exceeds considerably their supply [4]. This is especially true for small and medium-sized enterprises, which, for lack of granaries, need to storage grains for resale.

In addition, observing the dynamics of the total availability of cereals, leguminous crops and sunflower seeds at enterprises directly growing them, and at enterprises engaged in their storage and processing (Fig.2), it can be argued that farms are increasingly storing their crops in their own granaries. At the same time the quantity of storage of grain at the specialized enterprises decreases.This may be due to the lack of modern granaries and the desire of grain owners to reduce the cost of storing their crops in their own granaries.

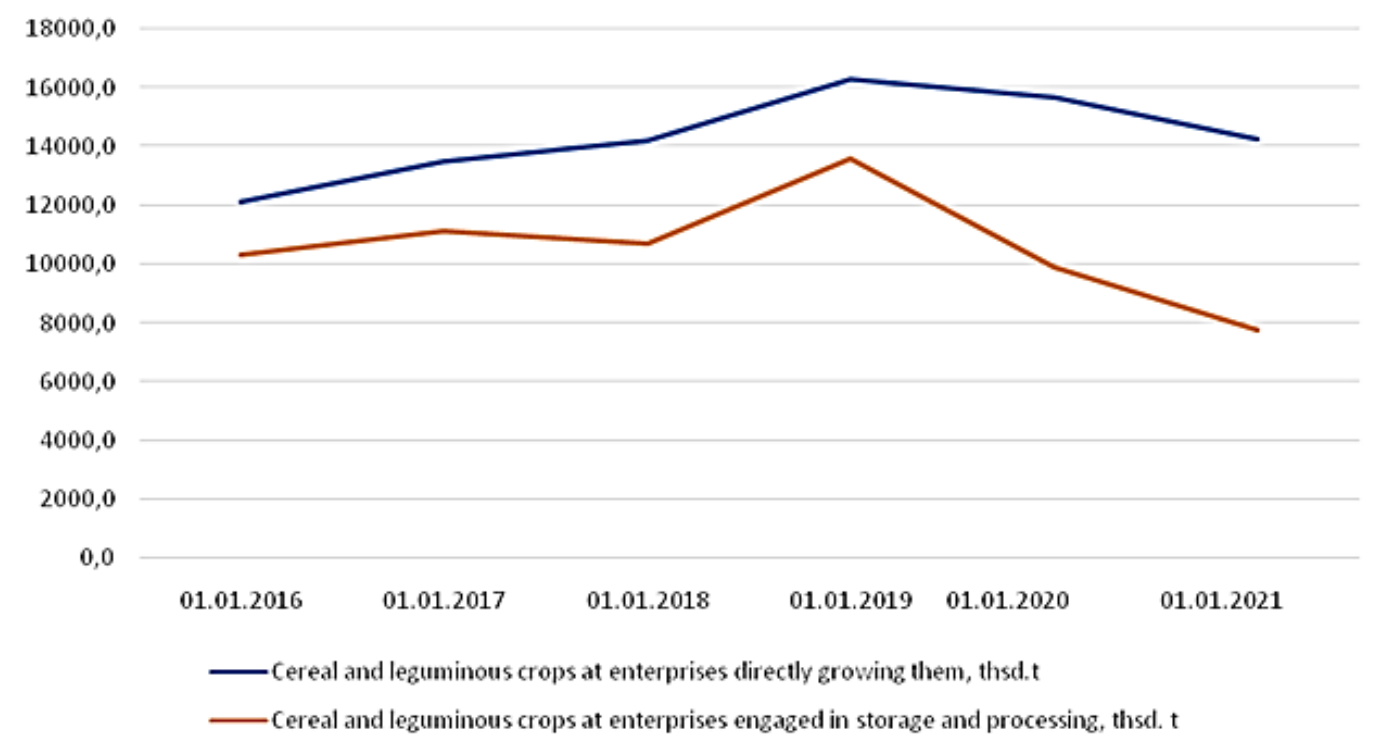

Fig. 2. Dynamics of the total availability of cereals, leguminous crops and sunflower seeds at enterprises directly growing them, and at enterprises engaged in their storage and processing

5. Method of transportation

Usually, grain is moved from the farm to the place of storage by a truck, a group of farmers' own trucks and grain wagons. According to [5], two thirds of grain produced in Ukraine is transported by rail. Grain 
shipments have grown sixfold in the last 18 years, demand and tariffs are high, but the quality of such shipments has not changed. Outdated rolling stock, shortage and untimely supply of wagons, as well as a complex mechanism for calculating the transportation cost contribute to the search for new opportunities for the transportation of grain crops

At the same time, the real cost of road transport has decreased in recent decades due to the increase in truck capacity, efficiency of truck engines and improvement of the regional roads quality.

Choosing the most optimal means of transport for the grain transportation allows the farm to reduce the cost of the logistics supply chain, which in turn will increase profitability and expand the country's agricultural sector.

Among the tools that will help to solve the problem mentioned above, it is worth noting the modeling of the supply chain logistics. In this case, such a tool must take into account all possible options for storage, transportation and sale of one or more grain species in order to maximize profits. In practice, it is also worth considering whether crops with higher yields, as well as vehicles with higher productivity, efficient reception centre, although they are more remote, will really contribute to a significant increase in farm profits.

To form a model of the grain crops supply chain, let's consider the process of grain delivery as a system that contains many acceptable alternatives for making the most rational decision.

The system is a set of interconnected elements, separated from the environment that interacts with it as a whole [6].

The process of grain crops delivery from the farm to the place of reception centre/internal consumer/ port terminal has all the features of the system, namely:

- is a holistic set of interconnected elements;

- forms a unity with the environment;

- is an element of the "supersystem";

- process elements can be lower order systems [7].

Let's form a semantic model (a formal model that is filled with a semantic essence from a given subject area, in other words terminologically "tied" to the object of modeling) of the grain crops logistics supply chain in the form of a "black box" model.

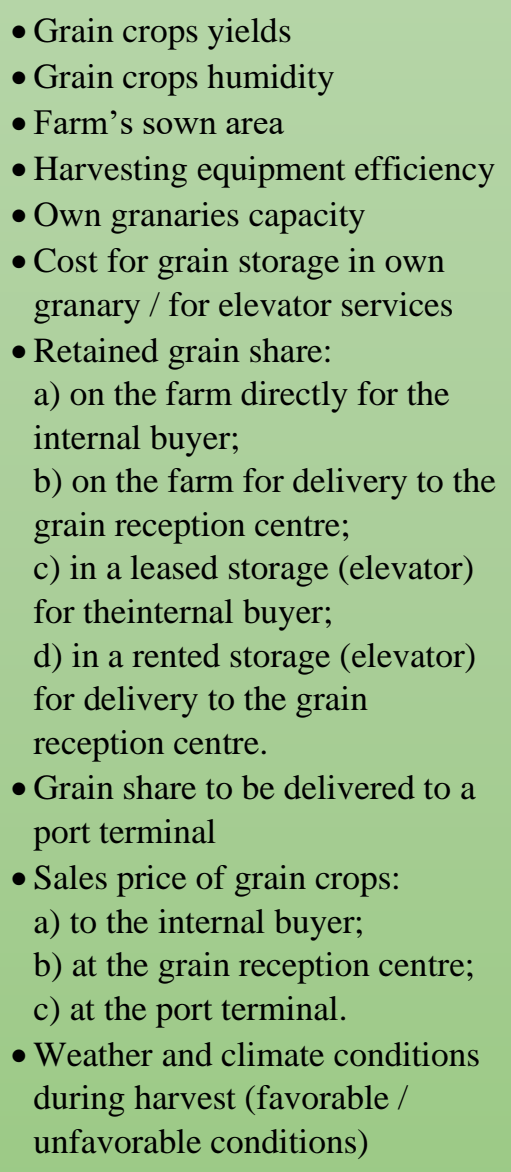

-Weather and climate conditions during harvest (favorable / unfavorable conditions)

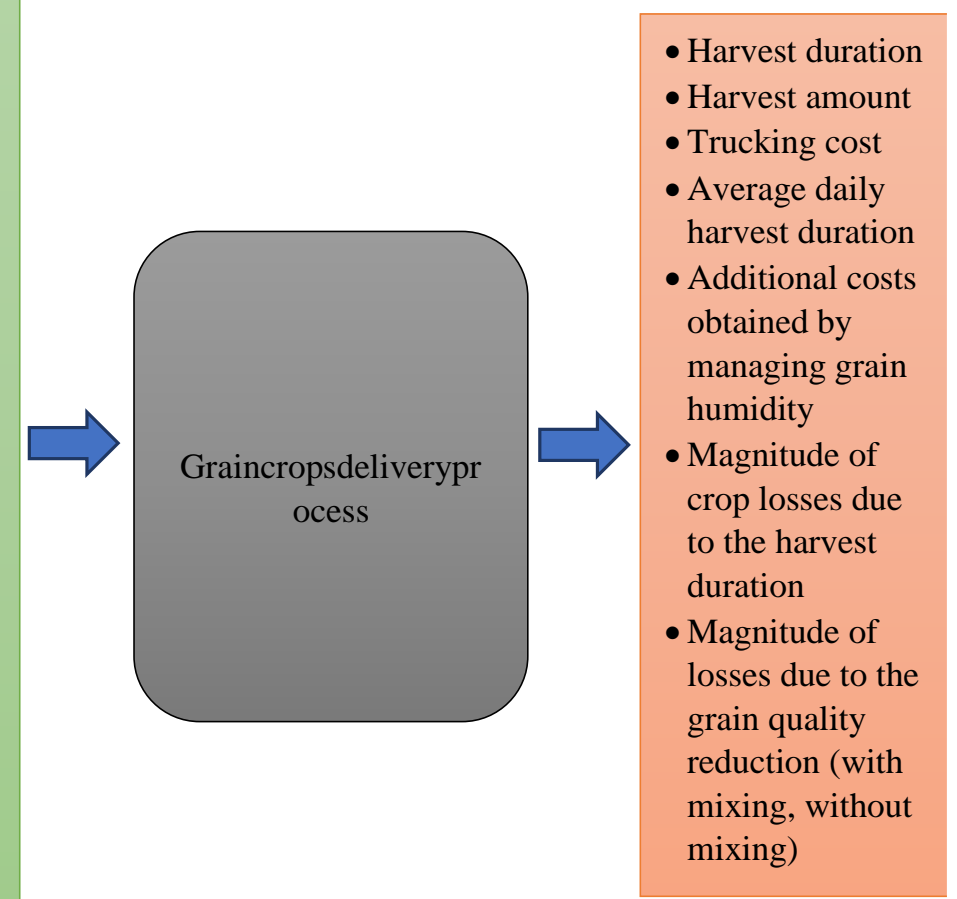


The "black box" model is the original model for building models of a complex system. This type of model allows us to consider the interaction of the system with the external environment. The model reflects the interaction of the system and the environment: 1) the impact of the system on the environment through the results of its purposeful operation that is through the target product (system outputs); 2) the influence of the external environment on the system through resource provision, management and various controlled and uncontrolled factors that contribute to or interfere with the normal functioning of the system (system inputs) [8].

The "black box" model should contain a clear criterion of efficiency, which will determine how close the solution is to the goal ("outputs") [9]. Figure 3 shows the model of the grain crops supply chain, the objective function of which for farms is to make a rational decision on the process of grain delivery in order to maximize profits by optimizing the costs of such supply chain and ensuring the development of farming as an activity.

If we consider each of the original variables, we can identify a number of factors that shape it. For example, the harvest duration depends on factors such as: area of grain crops, initial grain crops yield, number of days without reduced grain crops yield (such reduction usually occurs due to weather conditions, drying or damage by pests), harvest speed, technical and operational efficiency of vehicles, distance to the reception centre, as well as its working hours [10].

\section{Conclusions}

The proposed model will consider all these factors and their impact on harvesting, storage and transportation of grain crops, and will help to take into account the costs for farms depending on the situation. For example, for the sale of grain on the internal market through farm warehouses, the cost of grain processing will be zero, but for other supply chain routes grain processing costs will usually be incurred (which may be time-dependent or fixed). Even delivering grain directly from the farm to the port terminal can potentially incur grain handling costs through the use of third-party port infrastructure. That's why further research will allow us to consider all scenarios of the grain crops supply chain and to identify factors that will play a key role in profits forming of the farm and ensure its further development.

\section{REFERENCES}

[1] Програма розвитку фермерства України: дотації, програма підтримки молодого фермера, закон про локальне виробництво [Електронний ресурс]. Режим доступу до ресурсу: https://agropolit.com/spetsproekty/897-programa-rozvitkufermerstva-ukrayini-dotatsiyi-programa-pidtrimki-molodogo-fermera-zakon-pro-lokalne-virobnitstvo. Дата звернення: Жовт. 21 , 2021.

[2] Названо ТОП-10 агрохолдингів України за розміром земельного банку [Електронний ресурс]. Режим доступу: http://agroconf.org/content/nazvano-top-10-agroholdingiv-ukrayini-za-rozmirom-zemelnogo-banku. Дата звернення: Жовт. 14 , 2021.

[3] Обсяг виробництва, урожайність та зібрана площа сільськогосподарських культур за їх видами (2010-2020) / Державна служба статистики [Електронний ресурс]. Режим доступу : http://www.ukrstat.gov.ua. Дата звернення: Жовт. 16, 2021.

[4] Аналіз ринку елеваторів в Україні (pro-consulting.ua) [Електронний pecypc]. Режим доступу:https://proconsulting.ua/ua/issledovanie-rynka/analiz-rynka-elevatorov-v-ukraine-v-2016-5-mes-2019-gg. Дата звернення: Жовт. $25,2021$.

[5] "Золоте" зерноперевезення / Економічна правда [Електронний ресурс]. Режим доступу: https://www.epravda.com.ua/rus/columns/2021/02/1/670545/ Дата звернення: Жовт. 21, 2021.

[6] Ю. Г. Масікевич та ін., «Теорія систем в екології».Сумський державний університет.Суми, Україна, 2015.

[7] I. М. Дудник, «Вступ до загальної теорії систем». Полтава, Україна, 129с., 2010.

[8] А. С. Ачкасов та ін., «Теорія систем і системний аналіз : навч. посіб. для студентів ВНЗ»,Харків. наu. ун-m міс. госn-ва ім. О.М. Бекетова. Харків : ХНУМГ, 167 с., 2014.

[9] Д. С. Василега и др., «Моделирование систем управления: сборник лабораторных работ по дисциплине «Моделирование систем управления» для обучающихся по направлению 27.04.02 «Управление качеством»Тюменский индустриальный университет. Тюмень, Издательский центр БИК ТИУ, 2016. [Електронний ресурс]Режим доступу: http://elib.tyuiu.ru/wp-content/uploads/2016/05/16-183.pdf.Дата звернення: Жовт. 12 , 2021.

[10] Kingwell, Ross \& Loxton, Ryan \& Mardaneh, Elham. Factors and scenarios affecting a farmer's grain harvest logistics: A farmer's grain harvest logistics. Australian Journal of Agricultural and Resource Economics, 2019.

Kotenko Victoriia - Post-Graduate Student the Chair of Automobiles and transport management, e-mail: mialkovska.viktoria@gmail.com.

Vinnytsia National Technical University, Vinnytsia. 


\title{
В. І. Котенко
}

\section{Розробка моделі ланцюга постачання зернових культур}

\author{
Вінницький національний технічний університет
}

В роботі досліджено можливість оптимізації логістичного ланцюга постачання зернових культур із врахуванням інтересів фрермерського господарства. В процесі дослідження проаналізовано основні тенденції у аграрній галузі України, які прямо або опосередковано впливають на діяльність фермерського господарства.

Встановлено, що вибір найбільш оптимального виду перевезення зернових культур дозволяє фрермерському господарству знизити витрати на логістичний ланцюг постачання, а це в свою чергу призведе до зростання прибутковості та розширення аграрної галузі країни. Вирішення даної проблеми є можливим через моделювання логістичного ланиюга постачання врожаю. Для формування моделі логістичного ланцюга постачання зернових культур процес доставки зерна варто розелядати як систему, що містить у собі множину допустимих альтернатив для прийняття найбільш раціонального рішення. Запропонована модель представлена у вигляді моделі «чорного ящика». Цільова фрункція моделі полягає у прийнятті фрермерським господарством раціонального рішення щодо процесу доставки зернових культур з метою максимізації прибутку через оптимізацію витрат такого ланцюга постачання та забезпечення розвитку фермерства як виду діяльності.

Вхідними параметрами моделі визначено: врожайність та вологість зернових культур; посівні площі фрерми; продуктивність обладнання для збору врожаю; ємність власних зерносховищ; вартість зберігання зерна на власному зерносховищі або послуги елеватора; частку зерна, залежно від місця зберігання та продажу; ціну продажу зернової культури: внутрішньому покупцю, у пункті прийому зернових, у портовому терміналі, а також погодно-кліматичні умови під час збору врожаю (сприятливі або несприятливі умови).

Вихідними індикаторами, що характеризуватимуть успішність процесу доставки зернових виступатимуть наступні показники: тривалість збору врожаю, обсяг зібраного врожаю, витрати на автоперевезення, середньодобова тривалість збору врожаю, додаткові витрати, отримані за рахунок керування вологістю зерна, витрати врожаю через тривалість збору врожаю та витрати від зниження якості зерна (зі змішуванням, без змішування).

Запропонована модель дозволить розглянути всі ці фрактори та їх вплив на збір, зберігання та транспортування врожаю, а також допоможе врахувати витрати для фрермерського господарства залежно від ситуації.

Ключові слова:зернова логістика, фермерське господарство, ланцюг постачання, модель «чорний ящик».

Котенко Вікторія Ігорівна - аспірантка кафедри автомобілів та транспортного менеджменту, е-таil: mialkovska.viktoria@gmail.com.

\section{В. И. Котенко}

\section{Разработка модели цепи поставки зерновых культур}

\author{
Винницкий национальный технический университет
}

В работе исследована возможность оптимизации логистической цепи поставок зерновых культур с учетом интересов фрермерского хозяйства. В процессе исследования проанализированы основные тенденции в аграрной отрасли Украины, прямо или косвенно влияющие на деятельность фрермерского хозяйства.

Установлено, что выбор наиболее оптимального вида перевозки зерновых культур позволяет фрермерскому хозяйству снизить затраты на логистическую цепь снабжения, что приведет к росту прибыльности и расширению аграрной отрасли страны. Решение данной проблемы возможно через моделирование логистической цепи поставки урожая. Для формирования модели логистической цепи поставок зерновых культур процесс доставки зерна следует рассматривать как систему, содержащую в себе множество допустимых альтернатив для принятия наиболее рационального решения. Предложенная модель представлена в виде модели "черного ящика». Целевая функция модели состоит в принятии фермерским хозяйством рационального решения по процессу доставки зерновых культур с целью максимизации прибыли через оптимизацию затрат такой цепи снабжения и обеспечение развития фрермерства как вида деятельности.

Входными параметрами модели определены урожайность и влажность зерновых культур; посевные площади фермы; производительность оборудования для сбора урожая; емкость собственных зернохранилищ; стоимость хранения зерна на собственном зернохранилище или услуги элеватора; часть зерна, в зависимости от места хранения и продажи; цену продажи зерновой культуры: внутреннему покупателю, в пункте приема зерновых, в портовом терминале, а также погодно-климатические условия при сборе урожая (благоприятные или неблагоприятные условия).

Исходными индикаторами, которые будут характеризовать успешность процесса доставки зерновых, будут выступать следующие показатели: продолжительность сбора урожая, объем собранного урожая, расходы на автоперевозки, среднесуточная продолжительность сбора урожая, дополнительные расходы, полученные за счет управления влажностью зерна, расходы урожая из-за продолжительности сбора урожая и расходы от снижения качества зерна (со смешиванием, без смешивания).

Предложенная модель позволит рассмотреть все эти фракторы и их влияние на сбор, хранение и транспортировку урожая, а также поможет учесть затраты для фрермерского хозяйства в зависимости от ситуации.

Ключевые слова:зерновая логистика, фермерское хозяйство, цепочка снабжения, модель «черный ящик».

Котенко Виктория Игоревна - аспирантка кафедры автомобилей и транспортного менеджмента, е-таil: mialkovska.viktoria@gmail.com. 